DOI:

Ірина Кліщ, кандидат медичних наук, асистент кафедри патофізіології Івано-Франківського національного медичного університету

\title{
ВПРОВАДЖЕННЯ SМАRТ-ТЕХНОЛОГІЙ У ПРАКТИКУ ПІДГОТОВКИ МАЙБУТНІХ ВИКЛАДАЧІВ МЕДИЧНОГО ЗАКЛАДУ ВИЩОЇ ОСВІТИ
}

Статтю присвячено актуальній проблемі впровадження Smart-технологій у практику підготовки майбутніх викладачів медичних 3 ВО. Під поняттям "Sтаrt-технологї” розумісмо інформаційні технології, спрямовані на розвиток компетентностей учасників освітнього процесу, необхідних для успішної діяльності в умовах ииирового суспільства.

Досліджено, щуо тенденції переходу до Sтагt-технологій формують і нові вимоги до підготовки майбутніх викладачів: передбачають не подачу “готових" знань, а створення умов для придбання молоддю власного досвіду і навичок. Тобто за кониепиією Smart-навчання функиією викладача стає не трансляція готових істин, а якісна навігація контентом. Sтанt-технології дають змогу проводити динамічні презентації, демонструвати документи, сторінки Інтернету або відео на інтерактивному екрані, щцо сприяє підвищенню інтересу та поліпшенню концентрації уваги студентів $i$, як результат - кращому засвоєнню навчального матеріалу.

Ключові слова: технологія; smart; Smart-технологї; викладач; $3 В О$.

Jim. 8.

Iryna Klishch, Ph.D.(Medical Science), Assistant of the Pathophysiology Department Ivano-Frankivsk National Medical University

\section{SMART-TECHNOLOGIES IMPLEMENTATION IN FUTURE MEDICAL HEI TEACHER PRACTICAL PREPARATIONS}

The article is devoted to the topical problem of Smart-technologies in future medical HEI teacher practical preparations introduction. The concept of "smart technologies" means information technology, aimed at competencies development of educational process participants, required for digital society successful activity.

It is researched that the tendency of "smart technology" transition forms new requires for future teacher preparations. Do not provide ready knowledge, but condition creating for young people to acquire their own experience and skills.

According to the concept of smart learning, the function of the teacher is not the ready-made truths broadcasting, but high-quality content navigation.

Smart technology allows dynamic presentations holding, documents translating, internet pages or video broadcasting on an interactive screen, which helps to increase interest and students concentration improvement, and as a result, better material mastering.

It is established that at the current stage in the educational HEI environment, many Smart-technologies are used: interactive desk SMART board, Smart textbook, SMART projector, Software for creating and spreading educational content, which has interactive kind, social networks (Facebook, Twitter, Instagram, YouTube, blogs), services and tools Google, web-site Wiki, e-Learning etc., which activated development of the main approaches for "Smart technology" implementation during "Pathophysiology" learning in medical HEI.

It is concluded that "Smart technology" implementation in the educational process of the medical HEI radically changes obsolete model of knowledge transmission in the reproductive way into the new way, creative form of studying, which contributes stable motivation development of students for knowledge earning, new tools of knowledge searching in creative way.

Keywords: technology; smart; Smart-technology; a teacher; HEI.

П остановка проблеми. Перехід до інформаційного суспільства вносить свої корективи в усі сфери життєдіяльності людини. Нині майбутній викладач ЗВО повинен досконало володіти фаховими компетентностями; бути професійно мобільним, соціально активним; уміти генерувати, аналізувати і узагальнювати великі обсяги інформації; бути готовим до постійного самовдосконалення, самореалізації, саморозвитку. Тому постає потреба в перегляді технологій підготовки викладачів ЗВО, пошуку та використання інноваційних технологій, які грунтуються на нових досягненнях науки i гарантують результативність освітнього процесу у ЗВО. Однією із таких інноваційних технологій для підготовки викладачів медичного ЗВО можуть слугувати Smart-технології. 


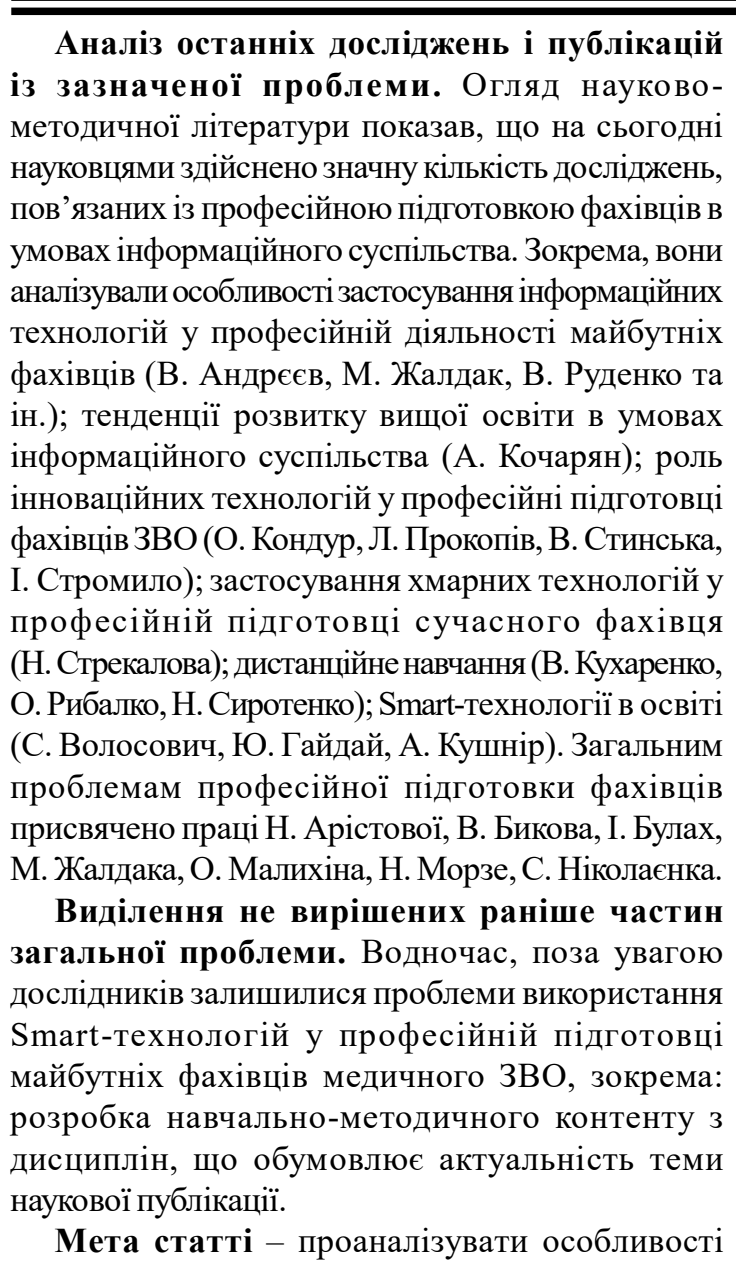
використання Smart-технологій у практиці підготовки майбутніх викладачів медичного ЗВО.

Виклад основного матеріалу. На сучасному етапі стратегічною метою реформування вищої освіти в Україні є створення ефективного інноваційного освітнього середовища в ЗВО шляхом сприяння прогресивним нововведенням, упровадження найсучасніших методів навчання, професійної мобільності та швидкої адаптації до змін у соціокультурній сфері, системі управління та організації праці в умовах ринкової економіки $[6,145]$.

Відтак, як свідчить дослідження А. Кушнір, “...без Smart-технологій інноваційна діяльність неможлива, адже саме Smart-технології дозволяють формувати індивідуальні траєкторії навчання для студентів (змішане навчання), оптимізувати використання електронних ресурсів 3 усього світу" $[4,40]$. Це, зі свого боку, створює нові можливості для системи освіти, що полягають у:

- інтеграції освітніх закладів у міжнародний освітній простір;

- охопленні додаткових категорій студентів, у тому числі й іноземних;
- застосуванні нових засобів та інноваційних освітніх технологій;

- створенні нових орієнтирів для викладачів, навчання та оцінки знань;

- посиленні наукових досліджень;

- впровадженні ефективніших моделей адміністрування та управління $[1,28]$.

Отже, SMART-технології - це вимога часу, стратегічний напрям розвитку вищої освіти, обумовлений стрімкою діджиталізацією всіх сфер суспільного життя. Персональні комп'ютери, ноутбуки, планшети, мультимедійна дошка, смартфони і т.д., а також наявність мережі Інтернет стали необхідними засобами в освітньому процесі і водночас технічною базою реалізації Smart-освіти.

Наш науковий пошук засвідчив, що aбревіатура SMART несе подвійне змістовне навантаження: крім дослівного перекладу 3 англійської - “розумне” навчання - пї̈ можна розшифрувати як навчання адаптивне, мотивоване, самостійне, збагачене ресурсами, 3 вбудованими технологіями $[1,27]$.

Термін “технологія” у довідковій літератури трактується як: 1) у перекладі із грецького “techne" - мистецтво, майстерність, уміння й сукупність методів обробки; 2) сукупність прийомів, застосовуваних у будь-якій справі; 3) сукупність способів обробки чи переробки матеріалів, інформації, виготовлення виробів, проведення різних виробничих операцій, надання послуг тощо $[3,71]$.

Узагальнюючи численні дослідження (А. Кушнір, Я. Крупський), під Smart-технологіями розуміємо інформаційні технології, спрямовані на розвиток компетентностей учасників освітнього процесу, необхідних для успішної діяльності в умовах цифрового суспільства.

Тенденції переходу до технологій Smart формують і нові вимоги до підготовки майбутніх викладачів. Smart-підходи передбачають не подачу “готових" знань, а створення умов для придбання молоддю власного досвіду і навичок. Тобто, за концепцією Smart-навчання функцією викладача стає не трансляція готових істин, а якісна навігація контентом.

У сучасному освітньому середовищі маємо багато Smart-технологій: інтерактивна дошка SMART Board, Smart-підручники, Smartпроєктори, програмне забезпечення для створення і поширення освітнього контенту, що має інтерактивний характер. На думку А. Кушнір, до Smart-технологій, можна віднести соціальні мережі (Facebook, Twitter, Instagram, Youtube, блоги), сервіси та інструменти Google, веб-сайт 
Wiki, e-Learning та ін. [4, 41]. Розглянемо деякі із них.

Iнтерактивна дошка SMART Board - це мультимедійний засіб зі всіма можливостями комп'ютера. Від звичайного монітора вона відрізняється сенсорним екраном великих розмірів та у комплекті з комп'ютером і мультимедійним проєктором складає програмно-технологічний навчальний комплекс. Можливості інтерактивної дошки великі. Якщо на звичайній дошці можна писати тільки крейдою, а на білій дошці маркером, то на інтерактивній можна писати маркерами кількох кольорів, робити письмові коментарі поверх зображення на екрані. Інтерактивна дошка може показувати зображення у кольорі (відео, анімації, слайди тощо), відтворити 3-D таких пристроїв в об'ємі та русі, реалізувати їх обертання у просторі. зберігати (запам'ятовувати) інформацію, роздруковувати i надсилати електронною поштою [7].

Отже, технологія SMART дає змогу проводити динамічні презентації, демонструвати документи, сторінки Інтернету або відео на інтерактивному екрані, що сприяє підвищенню інтересу та поліпшенню концентрації уваги студентів $\mathrm{i}$, як результат - кращому засвоєнню навчального матеріалу.

Smart-niдручники “ це навчальні контенти, інтегровані в інтерактивне середовище навчання, що містять графічний, відео- та аудіоматеріал, систему тестування, систему коментування контенту, систему оцінки контенту, самонаповнення і самоактуалізацію. Як правило, Smart-підручник складається 3 таких блоків: вивчення нового матеріалу, засвоєння навчального матеріалу, практичного застосування матеріалу, обговорення і контролю $[4,41]$.

e-Learning - система навчання, що грунтується на використанні інформаційних і електронних технологій. Часто тлумачиться як синонім таких понять: дистанційне навчання, навчання із застосуванням комп'ютерів, мережеве навчання, віртуальне навчання, мультимедійне навчання, мобільне навчання.

На відміну від навчання за допомогою Інтернету i мультимедіа, що передбачає використання дистанційних курсів, які пропонуються студентам 3 метою організації процесу навчання, e-Learning 2.0 передбачає використання засобів Веб 2.0: блогів, вікі, підкастів, соціальних мереж тощо. Спираючись на структуру побудови й функціонування еLearning 2.0, В. Стинська, О. Кондур, цитуючи В. Кухаренко, вказує такі його специфічні властивості: гнучкість і адаптивність до можливостей студентів; модульність; нова роль викладача (координатор); діагностика контролю якості знань (традиційні та дистанційні) форми контролю; використання спеціалізованих засобів навчання [8, 76].

Використання SMART-технологій у навчальному процесі дає змогу досягти таких позитивних результатів:

- збільшується обсяг зорової інформації, що підвищує якість та ефективність викладання;

- SMART-технології сприяють активній діяльності студентів, активізують їхній творчий потенціал;

- яскрава комп'ютерна графіка допомагає розвивати наочно-образне мислення;

- реалізується можливість опрацювання великої кількості інформації;

- створюються умови для індивідуальної дослідницької роботи з комп'ютерними моделями $[2,31]$

Отже, розглянемо основні підходи до впровадження SMART-технологій при вивченні дисципліни “Патофізіологія” у медичних ЗВО. Для створення навчально-методичного контенту дисципліни використовувалися інформаційні технології.

Покликаючись на дослідження [5, 39], на нашу думку, основними складовими створення контенту курсу $є$ :

- створення електронного курсу дисципліни “Патофізіологія" в системі дистанційного навчання TEAMS у вигляді модульної структури;

- формування модулів за результатами вивчення попередніх модулів і проходження проміжних тестів;

- створення у системі дистанційного навчання навчальних матеріалів із завчасно створеним педагогічним сценарієм (лекція зі зворотним зв'язком);

- впровадження мультимедійних навчальних засобів $з$ набором програмного забезпечення для інтерактивної дошки, використання пакетів прикладних програм з курсу;

- створення та впровадження засобів комп'ютерної діагностики студентів (індивідуальних завдань, багаторівневих тестів, ресурсів 3 можливостями додаткового опрацювання матеріалу для студентів 3 низьким рівнем підготовки).

Розкриємо зміст цих аспектів. Електронний курс дисципліни в системі TEAMS дає змогу викладачеві запропонувати студенту навчальні ресурси, які складно розкрити через обмеженість часу на аудиторних заняттях, зокрема подати відомості про відомих патофізіологів, історичні 
довідки, цікаві факти, матеріал для поглибленого вивчення, відеоматеріали. Означена система також уможливлює пояснювати теоретичний матеріал із застосуванням відеосупроводження, розв'язувати ситуаційні задачі за допомогою анімаційних елементів, проводити автоматичне оцінювання тестів та опитування студентів та ін. Зауважимо, що методичне забезпечення дисципліни повинно відповідати двом основним вимогам: узгоджуватися 3 програмою курсу та орієнтуватись на спеціальність студентів.

Висновки та перспективи подальших досліджень. Таким чином, впровадження Smartтехнологій в освітній процес медичного ЗВО кардинально змінює стару модель репродуктивної передачі знань на нову, креативну форму навчання, що сприяє створенню стійкої мотивації у студентів до отримання знань, пошук нових інструментів засвоєння цих знань за допомогою творчих рішень у студентів. Перспективи подальшого дослідження полягають у вивченні системи підготовки майбутніх викладачів медичного ЗВО.

\section{ЛІТЕРАТУРА}

1. Волосович С. Пріоритети розвитку смарттехнологій. Smart-освіта: ресурси та перспективи: матеріали Міжнар. наук.-метод. конф. (Київ, 16-17 жовтня 2014 р.), 2014. С. 27-29.

2. Гайдай Ю. Smart-технологія як інструмент активізації пізнавальної діяльності студентів. Smart-освіта: ресурси та перспективи : матеріали Міжнар. наук.-метод. конф. (Київ, 1617 жовтня 2014 р.), 2014. С. 29-31.

3. Крупський Я. В., Михалевич В. М. Тлумачний словник з інформаційно-педагогічних технологій : словник. Вінниця, 2010. 72 с.

4. Кушнір A.C. Smart-технології в освіті як чинник інформаційного розвитку суспільства. Молодий вчений. 2020. № 3.1 (79.1). С. 39-42.

5. Осадча К., Осадчий В., Спірін О., Круглик В. Реалізація індивідуалізації та персоналізації навчання засобами MOODLE. Молодь $і$ ринок, 2021. № 1 (187). C. 38-43.

6. Стинська В.В., Прокопів Л.М. Інноваційні методики викладання дисциплін у ЗВО в процесі магістерської підготовки. Гірська школа украӥнських Kарпат. 2020. № 22. С. 145 - 150.

7. Стромило I.M. Інтерактивні технології навчання. URL: http://conf.vntu.edu.ua/eiron/2013/ pdf/21.pdf. (дата звернення: 30.04.2021)

8. Stynska V.V., Kondur O. Strategies of professional preparation of the competitive specialist in the conditions of information environment. Contemporary technologies in the educational process monografia. Education in the post- coronavirus world: the place of information and innovative technologies, 2020. Publishing House of Katowice School of Technology, 2020. pp. 75-81.

\section{REFERENCES}

1. Volosovych, S. (2014). Priorytety rozvytku smart-tekhnolohii [Priorities for the development of smart technologies]. Smart-education: resources and prospects: Proceedings of the International. Scientific Method Conf. (Kyiv, October 16-17, 2014). pp. 27-29. [in Ukrainian].

2. Haidai, Yu. (2014). Smart-tekhnolohiia yak instrument aktyvizatsii piznavalnoi diialnosti studentiv [Smart-technology as a tool to enhance the cognitive activity of students]. Smart-education: resources and prospects: Proceedings of the International. Scientific Method Conf. (Kyiv, October 16-17, 2014). pp. 29-31. [in Ukrainian].

3. Krupskyi, Ya. V. \& Mykhalevych, V. M. (2010). Tlumachnyi slovnyk z informatsiinopedahohichnykh tekhnolohii [Explanatory dictionary of information and pedagogical technologies]. Dictionary. Vinnytsia, 72 p. [in Ukrainian].

4. Kushnir, A.S. (2020). Smart-tekhnolohii v osviti yak chynnyk informatsiinoho rozvytku suspilstva [Smart-technologies in education as a factor of information development of society]. A young scientist. No. 3.1 (79.1). pp. 39-42. [in Ukrainian].

5. Osadcha, K., Osadchyi, V., Spirin, O. \& Kruhlyk, V. (2021). Realizatsiia indyvidualizatsii ta personalizatsii navchannia zasobamy MOODLE [Implementation of individualization and personalization oflearning by means of MOODLE]. Youth \& market, No.1 (187). pp. 38-43. [in Ukrainian].

6. Stynska, V.V. \& Prokopiv, L.M. (2020). Innovatsiini metodyky vykladannia dystsyplin u ZVO $\mathrm{v}$ protsesi mahisterskoi pidhotovky [Innovative teaching methods in hei in the process of master's training]. Mountain school of the Ukrainian Carpathians. No. 22. pp. 145 - 150. [in Ukrainian].

7. Stromylo, I.M. (2013). Interaktyvni tekhnolohii navchannia [Interactive learning technologies]. Available at: http://conf.vntu.edu.ua/eiron/2013/pdf/ 21.pdf (Accessed 30 April 2021). [in Ukrainian].

8. Stynska, V.V. \& Kondur, O. (2020). Strategies of professional preparation of the competitive specialist in the conditions of information environment. Contemporary technologies in the educational process monografia. Education in the postcoronavirus world: the place of information and innovative technologies, Publishing House of Katowice School of Technology, pp. 75-81. [in English].

Стаття надійшла до редакції 15.03.2021 